\title{
DNA Barcode of Mountain White-Eye Zosterops montanus (Aves: Zosteropidae) Based on Mitochondrial DNA Cytochrome Oxidase Sub Unit I
}

\author{
Jarulis ${ }^{1, *}$ Melisa Mayang Sari ${ }^{2}$ Risky Hadi Wibowo ${ }^{1}$ \\ ${ }^{1}$ Department of Biology, Faculty of Mathematics and Natural Sciences, Bengkulu University, Indonesia \\ ${ }^{2}$ Undergraduate Student, Department of Biology, Faculty of Mathematics and Natural Sciences, Bengkulu \\ University, Indonesia \\ *Corresponding author.Email: jarulis@unib.ac.id
}

\begin{abstract}
The study aimed to describe the genetic characteristic, single nucleotide polymorphism, genetic distance, and phylogenetic of mountain white-eye Zosterops montanus based on mitochondrial DNA CO1 gene and carried out in March-June 2020. A sample of the bird was taken from Pasar Minggu, Bengkulu city. The blood sample was taken from the pectoral vein, and the DNA genome was isolated using DNeasy® Blood and Tissue Kit based on Spin-Column Protocol procedure, Qiagen. The CO1 gene was amplified using a polymerase chain reaction technique, electrophoresis on $1.2 \%$ agarose gel, and visualized with a UV transilluminator. The results showed that the gene size of CO1 mitochondrial DNA from Z. montanus $(\mathrm{n}=5)$ is $751 \mathrm{bp}$, obtained conservative sites (C) 745 sites, variations (V) six sites, the parsimony of information (Pi) four sites, and singleton sites (S) two sites. The highest nucleotide base composition was cytosine (C) and the lowest guanine (G), while the highest nucleotide combined composition of adenine-thymine (AT) and the lowest guanine-cytosine (GC). We found six single nucleotide polymorphisms were evenly distributed between 9-732 sites. Average intraspecific genetic distance was $0.4 \%$, interspecific genetic distance $4 \%$, and between groups 1 and 2 separated from the outgroup (group 3) with a genetic distance of $12.5 \%$.
\end{abstract}

Keywords: COI gene, DNA barcode, Zosterops montanus, Zosteropidae

\section{INTRODUCTION}

Indonesia is one of the ten countries with the largest biodiversity wealth in the world (mega diversity countries) after Colombia [1]. One of the diversity found in Indonesia is the type of bird. Indonesia has a very high diversity of bird species with some recorded birds, namely 1,589 species, 549 genera, 96 families, and 20 orders [2]. Unfortunately, now the number of birds in Indonesia tends to decrease. This can be caused by natural disasters, forest fires, poaching, habitat destruction, fragmentation, land-use change, illegal trade, and others.

Also, many people like to keep birds and participate in bird contests in various regions, causing positive and negative impacts. Some of the positive impacts, such as the development of a very profitable bird business with bird breeding activities by the community, the development of the bird trade in bird markets, the growing trade in bird cages, bird feed, medicines, and bird vitamins, thus providing income for the community [3], but the negative impact can make bird populations decrease, and even cause birds to be endangered.

One of the birds that are threatened by its existence mainly due to hunting and illegal trade is the mountain spectacle bird. This bird is one of the species of the Zosteropidae family which has grayishwhite feathers that surround the eyes, the body size is $11 \mathrm{~cm}$, upper body color is olive green, light gray stomach color with brown sides, besides the iris. his eyes also appear pale [4]. Mountain White-eye bird is a warbler. The natural enemies of this bird are snakes and other animals, but the most dangerous ones are humans [5]. Mountain White-eye Z. montanus into 
the IUCN red list of threatened species is at low risk (Least Concern) [6]. The increasing number of people, the more the needs, which can lead to reduced habitat or shelter, land-use change, rampant hunting, illegal trade, and others. Therefore, it is necessary to carry out genetic research related to the DNA of bird barcodes Mountain White-eye to be used as a database for further research.

The genetic marker used in studying, kinship, evolution, and genetic variation in various animal taxa is mitochondrial DNA [7]. Mitochondrial DNA has identical funding at the intra-species level of vertebrates because of its maternal inheritance pattern, which causes no recombination and high mutation rates. In the mitochondria, there are proteincoding genes, one of which is the $\mathrm{CO} 1$ gene or cytochrome oxidase subunit 1 [8]. CO1 gene has about 2000 base pairs defined as genes/markers barcode Internationally (The reference), but around 684-bp of the total length of these genes are believed to be used to identify animal species [9].

In the last few decades, the $\mathrm{CO} 1$ gene has been used as one of the founders of DNA because this CO1 gene has many advantages for studying genetic characteristics. After all, it has very few deletions and insertions in the sequence, and many parts are conserved, has a large number of copies. So, that it is easily amplified compared to genes originating from the nucleus so that it can be used as barcoding DNA in most species [10]. CO1 is also used as a study of phylogeny and population genetics [11], for the identification of Indonesian hornbills (Aves: Bucerotidae) [12] and genetic diversity in pheasants [13]. Research on the Zosterops montanus DNA barcode based on the mitochondrial DNA CO1 gene has never been carried out and the sequence data is not yet available in GenBank, so its status in the international classification is unclear. This study aims to obtain genetic characteristics, single nucleotide polymorphism, genetic distance, and phylogeny of the Zosterops montanus Mountain White-eye.

\section{MATERIALS AND METHODS}

This research was conducted in March-June 2020. Z. montanus samples were taken from Pasar Minggu, Bengkulu City, and further work was carried out at the Genetics and Biotechnology Laboratory, Basic Science Building, Biology Department, Faculty of Mathematics and Natural Sciences, Bengkulu University.

Mountain White-eye (Z. montanus) $\mathrm{n}=5$ were collected from traders who sell birds at the Sunday market in Bengkulu city and originate from the Kepahiang district. Blood samples were taken using a syringe size of $1 \mathrm{ml}$ as much as $0,5-1 \mathrm{ml}$ in the vein pectoral, and sampled direction is inserted into the vial containing EDTA for preservation, then stored in a freezer s hoot $-20^{\circ} \mathrm{C}$.

Total DNA isolation was carried out using Dneasy® Blood Kit and Tissue Kit cat no 69504 (50) based on the modified Qiagen Spin-column Protocol procedure. The quality of the isolated DNA was observed in $1.2 \%$ agarose gel using electrophoresis, then stored in a freezer of $-20^{\circ} \mathrm{C}$ before amplification.

CO1 gene amplification was carried out through an amplification process using the polymerase chain reaction (PCR) techniques. The primers used for $\mathrm{CO} 1$ amplification were designed using the tri primer program. The CO1 gene sequences used to design specific primers in this study came from the complete genome of mitochondrial DNA of the Zosterops erythropleurus type, which was found in GenBank with access code NC 027942 and the length of the CO1 sequence used was 1550 base pairs, namely ZCO1F (5'-TTCTGATTCTTTGGCCATCC-3') and ZCO1R (5'-GTTGGAAGGCTTTGCGT TTA-3').

The amplification reaction mixture using the PCR technique (total $25 \mu \mathrm{l}$ ) consisted of $\mathrm{ddH}_{2} \mathrm{O} 9.8 \mu \mathrm{l}$, Qs buffer $5.0 \mu \mathrm{l}$, Qs enhancer $5.0 \mu \mathrm{l}$, dNTP $1.0 \mu \mathrm{l}, 1.0 \mu \mathrm{l}$ forward primer, reverse primer $1.0 \mu \mathrm{l}$, DNA template $2 \mu \mathrm{l}$, and Taq polymerase $0.2 \mu \mathrm{l}$. The condition of the PCR machine when amped is as follows; predenaturation temperature $95{ }^{\circ} \mathrm{C}$ for 5 minutes, denaturation $94{ }^{\circ} \mathrm{C} 1$ minute, annealing $51{ }^{\circ} \mathrm{C} 45$ seconds, elongation $72{ }^{\circ} \mathrm{C} 1$ minute, past elongation $72{ }^{\circ} \mathrm{C} 6$ minutes, and cooling $4{ }^{\circ} \mathrm{C} 10$ minutes. The number of cycles of the denaturation-elongation stage is 35 times. DNA $(5.0 \mu \mathrm{l})$ PCR results were visualized on $1.2 \%$ agarose gel by electrophoresis and the results were photographed with UV transilluminator $(\lambda=300 \mathrm{~nm})$. DNA band PCR products that match the target are sent to the company PT. First Base Malaysia for sequencing.

The sequence of nucleotides (forward and reverse) is edited by alignment using the Clustal W program MEGA 6.0 [14]. BIOEDIT software version 7.0.9 [15], was used for editing the CO1 gene sequence, and for visualization of its electrogram and the sequence of its nucleotide bases. Each individual's $\mathrm{CO} 1$ gene sequence was aligned with the CO1 gene in GenBank through the Barcode of Life Database (BOLD) to see the similarity of the samples tested. The genetic distance between individuals was calculated using the Kimura 2-parameter (K2P) method [16]. The phylogeny tree was reconstructed 
Table 1. Number of samples used in data analysis.

\begin{tabular}{clcc}
\hline No. & Species name & Sample code & Sample locations \\
\hline 1 & Zosterops montanus & ZM1CO1 & Bengkulu \\
2 & Z. montanus & ZM2CO1 & Bengkulu \\
3 & Z. montanus & ZM3CO1 & Bengkulu \\
4 & Z. montanus & ZM4CO1 & Bengkulu \\
5 & Z. montanus & ZM5CO1 & New Zealand \\
6 & Z. lateralis & Access code NC_029146 & China \\
7 & Z. erythropleurus & Access code NC_027942 & Japan \\
8 & Z. japonicus & Access code KT_601061 & East Africa \\
9 & Z. poliogastrus & Access code NC_032059 & Southeast Kenya \\
10 & Z. abyssinicus & Access code NC_032058 & French \\
11 & Z. borbonicus & Access code MK_529728 & China \\
12 & Yuhina diademata & Access code NC_029462 & China \\
13 & Y. diademata & Access code KT_783535 & China \\
14 & Y. gularis & Access code MK_405666 & China \\
15 & Y. nigrimenta & Access code NC_040991 & China \\
\hline
\end{tabular}

Note: data number 6-16 are obtained from GenBank.

using the K2P Neighbor-Joining (NJ) model with 1000 replications [14]. The Mountain White-eye bird CO1 gene sequences contained in GenBank were downloaded and phylogeny tree constructions were included in the phylogeny tree reconstruction analysis.

\section{RESULT AND DISCUSSION}

\subsection{Gene DNA Size and Species Identification}

The result of electrophoresis in Figure 1 using a voltage of 50 Volt with a time of 45 minutes shows the size of DNA Z. montanus amplified by PCR technique according to the target planned at the time

of primary manufacture, namely 750 base pairs (bp). The PCR product is then followed by a sequencing process to obtain the nucleotide base sequence. Based on the sequencing results obtained throughout the length of the nucleotide sequence of individuals $(\mathrm{n}=5)$ with forward ranging between 751-762 bp, while reverse ranges between 752-757 bp. After editing using Bioedit and MEGA 6, the sequence used in the data analysis was $751 \mathrm{bp}$. The length of the $\mathrm{CO} 1$ gene sequence obtained in this study is different from previous studies, which is longer than the Indonesian Hornbill CO1 gene (Aves: Bucerotidae) which measures 746 bp [12], Parrots are $567 \mathrm{bp}$ [17] and Sea birds Thalasseus which measures 684 bp [18], but shorter than CO1 gene Cockatoo (Psittaciformes) measuring 807 bp [19]. The length of the $\mathrm{CO} 1$ gene sequence in this study is still included in the length of the sequence that is often used in species barcodes.

The length of the CO1 gene sequence used to barcode species ranges between half of the total length of the CO1 gene and is located at the base of the sequence of all animal species [20]. Even short sequences (109-208 bp) are also very useful in identifying species [21]. The Zosterops montanus CO1 sequences $(\mathrm{n}=5)$ of each individual (751 bp) were identified and matched with other Zosterops sequences available in GenBank in Table 2. CO1 gene identification is performed using the Barcode of Life Database (BOLD) System, online to see the percentage of the degree of similarity (similarity) CO1 gene of avian Mountain White-Eye (Zosterops montanus) available in GenBank.

The results of the BOLD System present the similarity value of all $Z$. montanus samples tested in Table 2. Three Zosterops spp species that were detected to have the highest similarity value with $Z$. montanus $(\mathrm{n}=5)$ were $Z$. erythropleurus with values ranging from 95.77 to $96.83 \%$ originating from China, Z. lateralis with values ranging from 94.18 $95.24 \%$ came from New Zealand and Z. polyogastrus ranged from 93.65 to $94.71 \%$ from East Africa. The three identified species of Zosterops spp come from outside Indonesia. This indicates that the CO1 $Z$. montanus gene nucleotide sequence is not yet available in GenBank. 


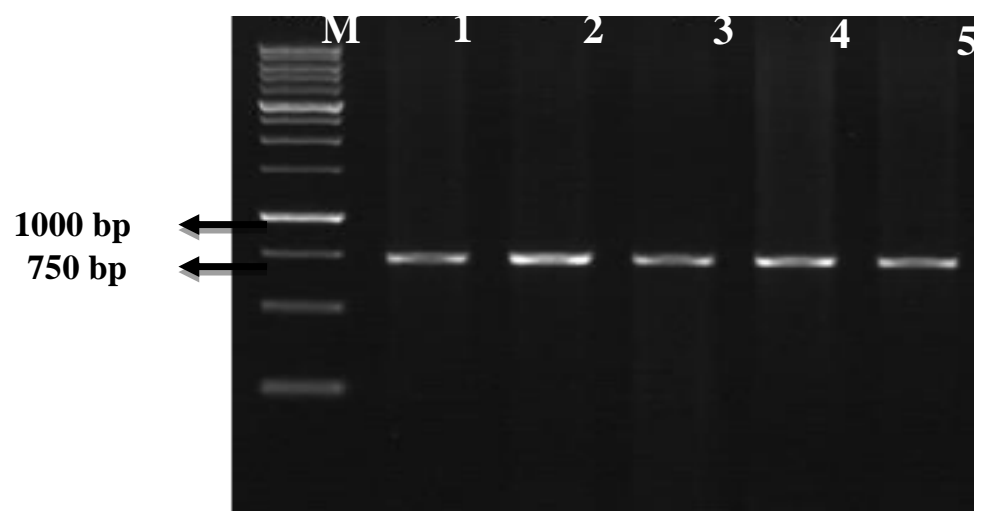

Figure 1. DNA band PCR result of CO1 Z. montanus gene. Information: $\mathrm{M}=$ Marker, $1=\mathrm{ZM} 1 \mathrm{CO} 1,2=$ ZM2CO1,

3 = ZM3CO1, 4 = ZM4CO1, 5 = ZM5CO1.

Table 2. Similarity of individual Z. montanus based on the results of the B OLD system of the CO1 gene length $751 \mathrm{bp}$.

\begin{tabular}{|c|c|c|c|}
\hline \multirow{2}{*}{ Sample } & \multicolumn{2}{|c|}{ BOLD System } & \multirow{2}{*}{ Country of Origin (Access Code) } \\
\hline & Control Species & Similarity $(\%)$ & \\
\hline \multirow[t]{3}{*}{ Z. montanus_ 1} & Z. erythropleurus & 96.83 & China (NC_027942) \\
\hline & Z. lateralis & 95.24 & New Zealand (NC_029146) \\
\hline & Z. poliogastrus & 94.71 & East Africa (NC_032059) \\
\hline \multirow[t]{3}{*}{ Z. montanus_ 2} & Z. erythropleurus & 96.83 & China (NC_027942) \\
\hline & Z. lateralis & 95.24 & New Zealand (NC_029146) \\
\hline & Z. poliogastrus & 94.71 & East Africa (NC_032059) \\
\hline \multirow[t]{3}{*}{ Z. montanus_3 } & Z. erythropleurus & 96.83 & China (NC_027942) \\
\hline & Z. lateralis & 95.24 & New Zealand (NC_029146) \\
\hline & Z. poliogastrus & 94.71 & East Africa (NC_032059) \\
\hline \multirow[t]{3}{*}{ Z. montanus_4 } & Z. erythropleurus & 95.77 & China (NC_027942) \\
\hline & Z. lateralis & 94.18 & New Zealand (NC_029146) \\
\hline & Z. poliogastrus & 93.65 & East Africa (NC_032059) \\
\hline \multirow[t]{3}{*}{ Z. montanus_ 5} & Z. erythropleurus & 96.83 & China (NC_027942) \\
\hline & Z. lateralis & 95.24 & New Zealand (NC_029146) \\
\hline & Z. poliogastrus & 94.71 & East Africa (NC_032059) \\
\hline
\end{tabular}

Note: control species data is obtained from the BOLD System linked to GenBank

Individual Zosterops montanus 1, 2, 3 and 5 had the highest similarity value with $Z$. erytropleurus $96.83 \%$, followed by $Z$. lateralis $95.24 \%$, and $Z$. poliogastrus $94.71 \%$, while $Z$. montanus_4 had a value Similarity was different from the other $4 Z$. montanus individuals, namely with the highest similarity value of $Z$. erytropleurus $95.77 \%, Z$. lateralis $94.18 \%$ and $Z$. poliogastrus $93.65 \%$. This difference can be caused because the Z. montanus_4 has higher mutations or more nucleotide differences compared to other individuals. The lower the similarity value, the higher the level of nucleotide differences between Z. montanus and other Zosterops spp.
The similarity value between all tested individuals has a similarity value of less than $97.0 \%$, so it can be stated that $Z$. montanus is a different species based on the CO1 gene with $Z$. erythropleurus, Z. lateralis, and Z. poliogastrus. According to Hebert et al. differences in similarity values between animal species have a threshold value of more than $3.0 \%$ [11].

\subsection{Variation and Composition of Nucleotides}

Based on the alignment of CO1 751 bp gene sequences, each individual Z. montanus $(n=5)$, obtained variations in nucleotides and nucleotide base compositions at the individual bird level. Mountain 
White-Eye are shown in Table 3. The number of nucleotide sites conservatif (C) $\mathrm{CO} 1$ gene 745 sites (99.2\%), variation sites (V) 6 sites (0.79\%), information parsimony sites (Pi) 4 sites $(0.53 \%)$, and singleton sites (S) 2 sites $(0.26 \%)$.

The number of conservative sites, variations, parsimony, and singleton results of this study seemed different from the results of previous studies. Jarulis et al, found that the Aceros hornbill CO1 gene with length $746 \mathrm{bp}$ had a conservative site of 737 sites $(98.79 \%)$, varied 9 sites $(1.2 \%)$, parsimony 0 sites $(0 \%)$, singleton 9 sites $(1,2 \%)$. In the genus Rhyticeros conservative sites 730 sites (97.8\%), variation 16 sites $(2.14 \%)$, parsimony 11 sites $(1.47 \%)$, singleton 5 sites $(0.6 \%)$. Whereas in the Buceros genus the conservative sites were 727 sites (97.3\%), the variation was 19 sites $(2.54 \%), 2$ sites parsimony (0.26\%), 17 singleton sites (2.27\%) [12]. Stated that the CO1 gene has advantages, namely conservative nucleotide sequences, slight deletions, insertions, and variations so that it is suitable for use as DNA barcoding [10].

The composition of each type of nucleotide base of 5 individual Z. montanus is shown in Table 3. The highest nucleotide base composition in all individuals was cytosine (C) which ranged between 28.1-28.6\% and the lowest was Guanine $(\mathrm{G})$ with a composition of $16.6 \%$. According to Avise, protein-coding genes including $\mathrm{CO} 1$ are characterized by high cytosine and low guanine compositions [22]. The composition of the nucleotide bases from this study is directly proportional to several previous studies. The Simpidan bird CO1 gene with the highest composition of cytosine (C) was $29.4 \%$ and the lowest was Guanine (G) $17.3 \%$ [13]. CO1 of Indonesian hornbills, especially Anthracoceros, has the highest and lowest nucleotide base composition, namely Cytosine (C) $31.9 \%$ and Guanine (G) $15.6 \%$, in Buceros namely Cytosine (C) $31.0 \%$ and the lowest is Guanine $(\mathrm{G}) .16 .3 \%$, and in Aceros, the highest was cytosine (C) $29.6 \%$ and the lowest was Guanine (G) $16.4 \%$ [12].

The composition of the AT Z. montanus base pair was higher than that of GC which ranged from 54.8$55.3 \%$ and $44.7-45.2 \%$ respectively. According to Sueoka, in invertebrates, GC content generally ranges from $40-45 \%$ [23]. The composition of the two base pairs from this study is in line with the results of Astuti et al. with a composition of $53.5 \%$ AT and $46.5 \%$ GC of the Simpidan (Lophura) bird's CO1 gene [13]. Jarulis et al. with the percentage composition of the nucleotide base pairs AT and GC in Hornbills (Aves: Bucerotidae), respectively 52.8\% and $47.2 \%$ [12]. Astuti and Sulandari found the base composition of AT and GC in cockatoos $51.9 \%$ and $48.2 \%$, respectively [19].

The results of the composition of the nucleotide base pairs are inversely proportional to the research of, with a low AT composition with a value of $48.9 \%$, while GC is higher with a value of $51.1 \%$ in eagles [24]. The composition of the nucleotide bases differs from one another can be caused by gene mutations. According to Karmana, the gene mutation is a difference that occurs in the DNA structure and the locus that does not change [25]. The difference in the number of nitrogen bases can cause the formation of different genes.

\subsection{Single Nucleotide Polymorphism (SNP)}

The results of alignment of nucleotide sequences using the $\mathrm{CO} 1$ gene between $\mathrm{Z}$. montanus individuals showed the presence of single nucleotide polymorphism (SNP) as a differentiator between $\mathrm{Z}$. montanus individuals as shown in Table 4. Based on tracking the number of single nucleotide polymorphisms, 6 specific sites were obtained from 5 individuals studied. Individual 1 has one specific site, namely number 474 , individual 2 has three specifics

Table 3. Conservative, varied sites and base composition of individual Z. montanus CO1 genes nucleotides with $751 \mathrm{bp}$.

\begin{tabular}{|c|c|c|c|c|c|c|c|c|}
\hline \multirow{2}{*}{ Sample } & \multirow{2}{*}{$\mathrm{C}$} & \multirow{2}{*}{$\mathrm{Vi}$} & \multirow{2}{*}{$\mathrm{Pi}$} & \multirow{2}{*}{$\mathrm{S}$} & \multicolumn{4}{|c|}{ Composition of Nucleotides $(\%)$} \\
\hline & & & & & $\mathrm{A}$ & $\mathrm{T}$ & G. & $\mathrm{C}$ \\
\hline Zosterops montanus_1 & & & & & 27.6 & 27.7 & 16.6 & 28.1 \\
\hline Zosterops montanus_2 & & & & & 27.4 & 27.3 & 16.6 & 28.6 \\
\hline Zosterops montanus_3 & 745 & 6 & 4 & 2 & 27.6 & 27.7 & 16.6 & 28.1 \\
\hline Zosterops montanus_4 & & & & & 27.4 & 27.4 & 16.6 & 28.5 \\
\hline Zosterops montanus_5 & & & & & 27.4 & 27.4 & 16.6 & 28.5 \\
\hline
\end{tabular}

Note: $\mathrm{C}=$ conservative site, $\mathrm{Vi}=$ variable site, $\mathrm{Pi}=$ information parsimony site, $\mathrm{S}=$ Singleton, $\mathrm{A}=\mathrm{Adenine}, \mathrm{T}$ $=$ Thymine, $\mathrm{G}=$ Guanine and $\mathrm{C}=$ Cytosine. 
Table 4. SNPs between individuals of Z. montanus based on the CO1 gene with a length of $751 \mathrm{bp}$.

\begin{tabular}{lcccccc}
\hline \multicolumn{1}{c}{ Individual (code) } & \multicolumn{5}{c}{ Nucleotide Sites } \\
\cline { 2 - 7 } & $\mathbf{9}$ & $\mathbf{1 0}$ & $\mathbf{1 9 8}$ & $\mathbf{4 7 4}$ & $\mathbf{5 1 3}$ & $\mathbf{7 3 2}$ \\
\hline Zosterops erythropleurus (NC_027942) & $\mathrm{C}$ & $\mathrm{T}$ & $\mathrm{T}$ & $\mathrm{C}$ & $\mathrm{T}$ & $\mathrm{T}$ \\
Zosterops montanus (1) &. &. &. & $\mathrm{A}$ &. &. \\
Zosterops montanus (2) &. &. & $\mathrm{C}$ &. & $\mathrm{C}$ & $\mathrm{C}$ \\
Zosterops montanus (3) &. &. &. &. &. &. \\
Zosterops montanus (4) & $\mathrm{T}$ & $\mathrm{C}$ & $\mathrm{C}$ & $\mathrm{A}$ & $\mathrm{C}$ &. \\
Zosterops montanus (5) &. &. & $\mathrm{C}$ &. &. & $\mathrm{C}$ \\
\hline
\end{tabular}

Note: Figures under the name s itus nucleotides are site IDs for each site based on the alignment of the gene CO1 length of 751 bp.

sites, namely, at numbers 198, 513, and 735, individual 4 has five specific sites, namely at numbers 9, 10, 198, 474, and 513, while individual 5 has two sites specific numbers, namely the numbers 513 and 732 .

SNP sites were evenly distributed along the $\mathrm{CO} 1$ gene sequence, namely from sites number 9 to 735 with the length of the CO1 sequence $751 \mathrm{bp}$. The results of this study are in line with Jarulis et al which received NSP between sequences number 84 and 737 on seven types of Indonesian hornbills [12]. The SNP sites obtained were genetic markers (species barcode) of Zosterops montanus and other types. So that it can be used to genetically identify Zosterops. Hebert et al, showed that the results of variations in the $\mathrm{CO} 1$ gene sequence can be used to distinguish types that are closely related to all taxa except the Cnidarians group [9]. Waugh (2007) said that each type has a specific nucleotide sequence with only slight differences in intraspecies [26].

\subsection{Genetic Distance}

Genetic Distance Results of Kimura 2-Parameter (K2P) analysis to determine the genetic distance between individuals of intraspecies $Z$. montanus, the genetic distance between $Z$. montanus and Zosterops in the same genus (GenBank data), and genetic distance between $Z$. montanus and Yuhina in the same family (GenBank data) shown in Tables 5 and 6. Based on the analysis results, it was found that the minimum value of intraspecies $Z$. montanus genetic distance was $0.0 \%$, the maximum value was $0.7 \%$ and the average was $0.4 \%$. The genetic distance between Z. montanus individuals is by research on the type of cockatoo, which has a genetic distance ranging between $0.1 \%$ and $0.7 \%$ [17]. According to Waugh, the intraspecies genetic distance is usually less than $1 \%$ and rarely more than $2 \%$ [26]. The minimum value of the genetic distance between $Z$. montanus and Zozterops species outside Indonesia is 0.030 (3\%), the maximum is $0.050(5 \%)$ and the average is $0.040(4 \%)$. Hebert et al. state that the difference in nucleotides and genetic distances of $3 \%$ between populations is a separate specie [27]. The minimum genetic distance between (Zosterops and Yuhina) of the Zosteropidae family is 0.117 (11.7\%), the maximum is $0.140(14 \%)$ and the average is $0.125(12.5 \%)$. This study is in line with the research of Huang and $\mathrm{Tu}$, which found that the average difference in the COI gene in the genus Ardeidae was $13.08 \%$ [28] and Yoo et al. in the Korean bird genera $8.2 \%$ [29]. Based on genetic distance, Z. montanus from Bengkulu has different species from 6 other Zosterops and 5 Yuhina.

Genetic distance is the level of difference in genes (nucleotide bases) in a species or population measured by numerical quantities [30]. Genetic distance can be used to determine the level of an animal's taxon at the species, genus, family, and higher levels. It can also describe the closeness between a species or in a population and is also used to see the closeness of genetic relationships between individuals [31].

Table 6. Genetic range mean intraspecies Z. montanus, interspecies Zosterops spp. and the intergenus Zosteropidae.

\begin{tabular}{|l|c|c|c|}
\hline \multicolumn{1}{|c|}{ Genetic distance } & Minimum (\%) & Average (\%) & Maximum (\%) \\
\hline Intraspecies Z. montanus & 0.0 & 0.4 & 0.7 \\
\hline Intraspecies Z. montanus vs Zosterops spp. & 3.0 & 4.0 & 5.0 \\
\hline Zosterops spp. vs Yuhina spp. & 11.7 & 12.5 & 14.0 \\
\hline
\end{tabular}


Table 5. Genetic distance matrix Pairwise distance intraspecies Z. Montanus, interspecies Zozterops, family intergenus Zosteropidae

\begin{tabular}{|c|c|c|c|c|c|c|c|c|c|c|c|c|c|c|c|c|}
\hline species & 1 & 2 & 3 & 4 & 5 & 6 & 7 & 8 & 9 & 10 & 11 & 12 & 13 & 14 & 15 & 16 \\
\hline \multicolumn{17}{|l|}{ Z. montanus_1 } \\
\hline Z. montanus_3 & 0.004 & & & & & & & & & & & & & & & \\
\hline Z. montanus_2 & 0.001 & 0.005 & & & & & & & & & & & & & & \\
\hline Z. montanus_4 & 0.005 & 0.007 & 0.004 & & & & & & & & & & & & & \\
\hline Z. montanus_5 & 0.005 & 0.007 & 0.004 & 0.000 & & & & & & & & & & & & \\
\hline $\begin{array}{l}\text { Z. lateralis } \\
\left(N C \_029146\right)\end{array}$ & 0.034 & 0.039 & 0.033 & 0.037 & 0.037 & & & & & & & & & & & \\
\hline $\begin{array}{l}\text { Z. erythropleurus } \\
\left(N C \_027942\right)\end{array}$ & 0.033 & 0.034 & 0.031 & 0.030 & 0.030 & 0.037 & & & & & & & & & & \\
\hline $\begin{array}{l}\text { Z. japonicus } \\
\text { (KT_601061) }\end{array}$ & 0.047 & 0.048 & 0.046 & 0.044 & 0.044 & 0.037 & 0.033 & & & & & & & & & \\
\hline $\begin{array}{l}\text { Z. poliogastrus } \\
\text { (NC_032059) }\end{array}$ & 0.037 & 0.041 & 0.036 & 0.037 & 0.037 & 0.039 & 0.033 & 0.044 & & & & & & & & \\
\hline $\begin{array}{l}\text { Z. abyssinicus } \\
\text { (NC_032058) }\end{array}$ & 0.041 & 0.046 & 0.040 & 0.042 & 0.042 & 0.037 & 0.036 & 0.046 & 0.012 & & & & & & & \\
\hline $\begin{array}{l}\text { Z. borbonicus } \\
\text { (MK_529728) }\end{array}$ & 0.050 & 0.054 & 0.049 & 0.049 & 0.049 & 0.046 & 0.047 & 0.05 & 0.039 & 0.043 & & & & & & \\
\hline $\begin{array}{l}\text { Yuhina diademata } \\
\text { (NC_029462) }\end{array}$ & 0.135 & 0.140 & 0.136 & 0.138 & 0.138 & 0.143 & 0.136 & 0.138 & 0.137 & 0.139 & 0.130 & & & & & \\
\hline $\begin{array}{l}Y . \text { diademata } \\
\left(K T_{-} 783535\right)\end{array}$ & 0.135 & 0.040 & 0.136 & 0.138 & 0.138 & 0.143 & 0.136 & 0.138 & 0.137 & 0.139 & 0.130 & 0.000 & & & & \\
\hline $\begin{array}{l}\text { Y. gularis } \\
\left(M K_{-} 405666\right)\end{array}$ & 0.128 & 0.132 & 0.126 & 0.131 & 0.131 & 0.122 & 0.116 & 0.128 & 0.117 & 0.119 & 0.12 & 0.127 & 0.127 & & & \\
\hline $\begin{array}{l}\text { Y. nigrimenta } \\
\left(N C \_040991\right)\end{array}$ & 0.118 & 0.123 & 0.117 & 0.122 & 0.122 & 0.114 & 0.112 & 0.105 & 0.106 & 0.110 & 0.117 & 0.114 & 0.114 & 0.085 & & \\
\hline $\begin{array}{l}Y . \text { nigrimenta } \\
\text { (MH_916608) }\end{array}$ & 0.118 & 0.123 & 0.117 & 0.122 & 0.122 & 0.114 & 0.112 & 0.105 & 0.106 & 0.110 & 0.117 & 0.114 & 0.114 & 0.085 & 0.000 & \\
\hline
\end{tabular}






Figure 2. The phylogenetic tree was reconstructed using the $\mathrm{K} 2 \mathrm{P}$ model and the NeighborJoining (NJ) bootstrap 1000 times based on the CO1 gene (751 bp).

\subsection{Phylogenetic}

A phylogenetic tree is a branch diagram depicting an arrangement of kinship relationships in a particular population or group [30]. The results of phylogenetic tree reconstruction using the K2P Neighbor-Joining (NJ) model with 1000 replications are shown in Figure 2. The results of phylogenetic tree analysis showed the separation of genetic distances into 3 groups. Group I consisted of 5 individuals, namely the $Z$. montanus bird studied, while $Z$. lateralis, $Z$. erythropleurus, Z. japonicas, Z. poliogastrus, Z. abyssinicus, $\quad Z$. borbonicus formed group II and Yuhina diademata, $Y$. gularis, $\quad Y$ nigrimenta formed a separate group III.

The genetic distance of $Z$. montanus $(\mathrm{n}=5) 0.004$ $(0.4 \%)$ with a fairly high bootstrap value between 59 and 100. Group I and group II were separated by a genetic distance of 0.040 $(4 \%)$, the bootstrap values ranged between 31 and 100, whereas between groups I and II separated with outgroup (group III) with a genetic distance of $0.125(12.5 \%)$. Differences in nucleotide and a 3\% genetic distance between populations is a separate species [27]. The bootstrap value shows the closeness between one species and another, which is used to test how well the model data set we use is [32]. The $\mathrm{CO} 1$ gene is very effective as a DNA barcode due to the low variation between species while between species is high, especially in adjacent taxa [21].

Branch tree phylogenetic represents the relationship between the unit and describes the relationship hereditary, while the length of branch represents the number of evolutionary changes that occurred between two nodes [33]. Two sequences that have many similarities will be in one branch [32]. The diversity of $\mathrm{CO} 1$ gene sequences (648 bp) maintains a potential use for identification at the species level, and serves as a DNA barcode [8].

\section{CONCLUSION}

Based on the results of research on birds $Z$. montanus $(\mathrm{n}=5)$ mitochondrial DNA CO1 gene size $751 \mathrm{bp}$, it was found that conservative sites (C) 745 
sites (99.2\%), variation (V) 6 sites (0.79\%), parsimony information (Pi) 4 sites (0.53\%), and singleton sites (S) 2 sites $(0.26 \%)$. The highest composition of nucleotide bases was Cytosine (C) ranging from $28.1-28.6 \%$ and the lowest was Guanine (G) 16.6\%, while the highest nucleotide composite composition was AT ranged from 54.8$55.3 \%$, the lowest was GC. between 44.7$45.2 \%$. There are six specific sites that are evenly distributed between sites 9-732 number. The average genetic distance of individual Z. montanus was $0.4 \%$ (group I), separated from other Zosterops spp. (Group II) with $4 \%$ genetic distance, group 1 and 2 were separated from outgroup (group III) with a genetic distance of $12.5 \%$.

\section{ACKNOWLEDGMENTS}

We would like to thank Drs. Muslim Choirul, SU., Ph.D. and Santi Nurul Kamilah, S.Si., M.Si. which has helped in the improvement of this article. We also express our appreciation to friends in the zoology laboratory who have helped during the research

\section{REFERENCES}

[1] W. Novarino, Kobayashi, A. Salsabila, Jarulis, M.N Janra, Field Guide of Bird-Washing in Sumatra, National Library, 2008.

[2] Sukmantoro, M. Irham, W. Novarino, F. Hasudungan, N. Kemp, M. Muchtar, Daftar Burung Indonesia No.2, Indonesia Ornithologists' Union, 2007. [In Bahasa Indonesia]

[3] J. Iskandar, The dilemma between the hobby and business of bird trade and bird conservation, Chimica et Natura Acta 2 (3) (2014) 180-185.

[4] J. Mackinnon, K. Philipps, B. Balen, Birds in Sumatra, Java, Bali and Kalimantan (Including Sabah, Sarawak and Brunei Darussalam), LIPI Biology, 2010. [In Bahasa Indonesia]

[5] I. Yuwono, Pleci, PT AgroMedia Pustaka, 2013. [In Bahasa Indonesia]

[6] IUCN, Bird Life International Zosterops japonicus, The IUCN Red List of Threatened Species 2019: e.T155158005A155636070, 2019.

[7] T.D. Kocher, W.K. Thomas, A. Meyer, S.V. Edwards, S. Paabo, F.X. Villablanca, A.C. Wilson, Dynamics of Mitochondrial DNA
Evolution in Animals: Amplification and Sequencing with Conserved Primers, Proc. Nati. Acad. Sci. USA, vol. 86, 1989: pp. 6196-6200.

[8] P.D.N. Hebert, M.Y. Stoeckle, T.S. Zemlak, and C.M. Francis, Identification of birds through DNA barcodes, PLoS Biol 2(10) (2004) 312.

[9] P.D.N. Hebert, S. Ratnasingham, J.R. DeWaard,Barcoding Animal Life: Cytochrome C Oxidase Subunit 1 Divergences Among Closely Related Species, Proceedings of the Royal Society B: Biological Sciences, vol. 270, 2003.

DOI: https://doi.org/10.1098/rsbl.2003.0025.

[10] M.S.A. Zein, D.M Prawiradilga, DNA Barcode Fauna Indonesia, Kencana Prenadamedia, 2013. [In Bahasa Indonesia]

[11] M. Hajibabaei, G.A.C. Singer, P.D.N. Hebert, D.A. Hickey, DNA Barcoding: How it Complements Taxonomy, Molecular Phylogenetics and Population Genetics, Trends in Genetics, 2007, pp. 167-172. DOI: https://doi.org/10.1016/j.tig.2007.02.001.

[12] Jarulis, D.D. Solihin, A. Mardiastuti, L.B. Prasetyo, DNA Barcode of Seven Indonesian Hornbills Species (Aves: Bucerotidae) Based on Mitochondrial DNA Cytochrome Oxidase Subunit I, HAYATI Journal of Biosciences 25(4) (2018) 178-187. DOI: https://doi.org/10.4308/hjb.25.4.178.

[13] D. Astuti, M. Irham, H. Ashari, COI Gene Nucleotide Variations in Narrow Bird (Genus Lophura), Indonesian Biology 14(1) (2018) 103-108.

[14] K. Tamura, G. Stecher, D. Peterson, A. Filipski, S. Kumar, MEGA6 Molecular Evolutionary Genetics Analysis Version 6.0. Molecular Biology dan Evolution (2013) 1-5. DOI: https://doi.org/10.1093/molbev/mst197.

[15] T.A. Hall, BioEdit: a User-Friendly Biological Sequence Alignment Editor dan Analysis Program for Windows 95/98NT, vol.41, Nucleic Acids Symposium Series, 1999 pp. 9598.

[16] M. Kimura, A Simple Method for Estimating Evolutionary Rates of Base Substitutions Through Comparative Studies of Nucleotide 
Sequences. vol. 16, Journal of Molecular Evolution, 1980, pp. 111-120.

[17] P.F.M Goncalves, A.R Oliveira-Marques, T.E. Matsumoto, C.Y. Miyaki, DNA Barcoding Identifies Illegal Parrot Trade. Journal of Heredity, 106(1) (2015) 560-564. DOI: https://doi.org/10.1093/jhered/esv035.

[18] M.A. Efe, E.S. Tavares, A.J. Baker, S.L. Bonatto, Multigene Phylogeny and DNA Barcoding Indicate that the Sdanwich Tern Complex (Thalasseus sandvicensis, Laridae, Sternini) Comprises Two Species, Molecular Phylogenetics dan Evolution 52(1) (2009) 263267.

DOI: https://doi.org/10.1016/j.ympev.2009.03.00.

[19] D. Astuti, S. Sulandari, The DNA Sequence Performance of CO1 Gene in White Cockatoos (Cacatua, Psittaciformes), Treubia 37 (2010) pp. $1-14$

[20] S. Sammler, C. Bleidorn, R. Tiedemann, Full Mitochondrial Genome Sequences of Two Endemic Philippine Hornbill Species (Aves: Bucerotidae) Provide Evidence for Pervasive Mitochondrial DNA Recombination, BMC Genomics 2011, pp. 1-10. DOI: https://doi.org/10.1186/1471-2164-12-35.

[21] M. Hajibabaei, M.A. Smith, D.H. Janzen, J.J. Rodriguez, J.B. Whitfield, and P.D.N. Hebert, A Minimalist Barcode Can Identify a Specimen whose DNA is Degraded, Molecular Ecology Notes 6(4) (2006) 959-964. DOI: https://doi.org/10.1111/j.14718286.2006.01470. X.

[22] J.C. Avise, Molecular Markers, Natural History and Evolution. Chapman and Hall, 1994

[23] N. Sueoka, On the Genetic Basis of Variation dan Heterogeneity of DNA Base Composition. Genetics, vol. 48 (1962) pp. 582-591.

[24] M.S.A. Zein, DNA Barcode of the Eagle (Family Accipitridae) in Indonesia, LIPI 17(2) (2018) 165-173.

[25] O. Karmana, Biology, Grafindo Media First, 2008

[26] J. Waugh, DNA Barcoding in Animal Species: Progress, Potential dan Pitfalls, BioEssays 29(2)
(2007) pp. 188-197. DOI: https://doi.org/10.1002/bies.20529.

[27] P.D.N. Hebert, A. Cywinska, S.L. Ball, J.R. DeWaard, Biological Identifications Through DNA barcodes, The Royal Society 270 (2003) pp. 313-321.

[28] Z. Huang, F. Tu, DNA Barcoding dan Phylogeny of Calidris and Tringa (Aves: Scolopacidae), Mitochondrial DNA 28(4) (2016) 616-619. DOI: https://doi.org/10.3109/24701394.2016.1155121

[29] H. Yoo, J. Eah, J. Kim, Y. Kim, M. Min, W. Paek, C. Kim, DNA Barcoding Korean Birds, Molecules and Cells 35(4) (2013) pp. 357. DOI: https://doi.org/10.1007/s10059-013-3151-6.

[30] M. Nei, S. Kumar, Molecular Evolution and Phylogenetics, Oxford University Press, 2000.

[31] Wirdateti, E. Indriana, Handayani, Analysis on Mitochondrial DNA Cytochrome Oxidase I (COI) Sequences of Indonesia Slow Lories (Nycticebus spp) as Marker to Improve Identification of Species, 12(1) (2016) 119-128. DOI: https://doi.org/10.14203/jbi.v12i1.2322.

[32] I. Dharmayanti, Molecular Phylogenetics: Taxonomic Methods of Organisms Based on the History of Evolution, WARTAZOA 21(1) (2011) 1-9.

[33] D. Graur, W. Li,. Fundamental of Molecular Evolution Second Edition. Sinauer Associates Inc. Sunderland, (2010) DOI: https://doi.org/10.1016/B978-1 4557-51341.00001-9. 